\title{
Facilitating Autonomy and Creativity in Second Language Learning through Cyber-tasks, Hyperlinks and Net-surfing
}

\author{
AKINWAMIDE, T. K. \\ Ekiti State University, Ado Ekiti, Nigeria \\ E-mail: akinwamidetim@rocketmail.com \\ ADEDARA, O. G. \\ Federal Polytechnics Ado Ekiti, Nigeria \\ E-mail: fafvfk@yahoo.com
}

Received: April 4, 2012

Accepted: April 24, 2012

Published: June 1, 2012

doi:10.5539/elt.v5n6p36

URL: http://dx.doi.org/10.5539/elt.v5n6p36

\begin{abstract}
The digitalization of academic interactions and collaborations in this present technologically conscious world is making collaborations between technology and pedagogy in the teaching and learning processes to display logical and systematic reasoning rather than the usual stereotyped informed decisions. This simply means, pedagogically, learning is being revolutionized with visible transformation from quantity to higher quality. Through independent, self-paced learning; students interact with technologies to review, construct, analyze, and make submissions. It is to be noted that the inclusion of information and communication technology (ICT) into Language education gives vent to new learning paradigms in language education and this in a way concomitantly redefines the role of the teacher as well as repositions the cognition level of the learners. This paper therefore intents to beam searchlight on possible strategy for achieving autonomy in second language learning through digitalization. It is to be noted that the challenges of second language learners may not be resolved totally in the language classroom, hence there is the need for the teacher to become a facilitator thereby paving way for students' self- discovery through different cyber-tasks and navigating system inherent in this computer infested world. This paper therefore displays a phase of digitalized pedagogy in the language classroom.
\end{abstract}

Keywords: Pedagogy, Creativity, Digitalization, Originality

\section{Introduction}

The interactions between technology and pedagogy stand to put both teachers and learners on their 'academic toes' for improving and developing the modern society. There are many learning styles and disposition to learning differs with individuals. There is a part of the brain that supports the different learning styles as stated below.

$>$ Audio : one prefers using sound for learning.

$>$ Logical : one prefers the application of logic and reasoning.

$>$ Physical : one prefers to learn by touching physical objects.

$>$ Social : one prefers to learn interacting with other people.

$>$ Solitary: one prefers to work in solitude.

$>\quad$ Verbal : one prefers learning through words, speech and writing.

$>$ Visual : one learns better through pictorial presentations.

Now with the advancement in technology, it can be rightly posited that one can learn better and soar higher in the field of education. With the eclectic nature of a professional language teacher, different learning styles can be employed to ameliorate the initial constraints of second language learners. The learning styles are the result of the combinations of different personal and situational preferences that lead to the employment of a certain set of learning strategies. These preferences are determined by cognitive, psychological, socio-cultural variables as well as educational objectives, attitudes towards beliefs, perception on learning limitations and skills.

Over the years, many teachers downplayed the importance of utilizing the privilege inherent in inculcating 
knowledge through the appropriate learning style because of ignorance, self-limitations and the dearth of technological- know-how to display the appropriate learning style. Researchers in computer science believe that technology is able to provide students and researchers with powerful tools that can expand their understanding of the world and our place within it. By running simulations, conducting statistical analysis, analyzing text, or searching databases, students today can perform experiments that would have been impossible only a few years ago. It is the responsibility of the teacher to set the students forward; the students in turn stand to discover a lot of insights that further enlighten and accelerate learning. Combining a mixture of approaches and teaching methods, students are able to choose the instruction that best fits their individual learning style with the aid of modern technology.

\section{Creativity in the Language Classroom}

The West African Examinations Council (WAEC) and National Examinations Council (NECO) want the students to be creative in their writing approach. It is imperative to know why creativity in the language classroom is very important especially in a second language environment. Akinwamide (2007) itemizes eight facts in respect of this sub-skill development.

(1) Language use is a generative art which gives credence to originality and results in creativity. Internalized thoughts and concepts are transformed into language that can be heard or read. We are capable of producing sentences and even long texts that we have never read or heard. By giving learners creative exercises, we get them to practice an important sub-skill of using a language; thinking creatively.

(2) Creativity triggers learning: Self-pace learning is possible through the use of modern technology; new things are discovered in the process of browsing the net the result of which brings about a new line of thought.

(3) Motivating Power in realization of new ways of solving a given problem, hence some people become motivated as a result of inspiration which makes them to create something of value.

(4) Creativity Improves Self-esteem: This is what makes learners to develop confidence in their ability for self-procured solutions to challenges.

(5) Creative work in the Language Classroom can lead to genuine communication and cooperation. Learners use the language to do the creative task; so they use it as a tool, in its original function. This prepares learners for using the language instrumentally outside the classroom.

(6) Creative tasks enrich classroom work. This opens the way for exciting and thrilling academic atmosphere. The tasks make the classroom work varied and more innovative by tapping into individual talents; ideas and thoughts both the learners' and the teachers',

(7) Creative Thinking is an important skill in real life. It is part of our survival strategies and it is the force behind personal growth.

Now, why is creativity so important?

$\diamond \quad$ Creativity Improves Pupils' Self-esteem, Motivation and Achievement.

$>$ Pupils who are encouraged to think creatively and independently become:

$>$ more interested in discovering things for themselves.

$>$ more open to new ideas.

$>$ keen to work with others to explore ideas.

$>$ willing to work beyond lesson time when pursuing an idea or vision.

As a result, their pace of learning, levels of achievement and self-esteem increase.

$\diamond \quad$ Creativity Prepares Pupils for Life: The students who are creative will be prepared for a rapidly changing world, where they may have to adapt to several careers in a life time. Many employers want people, who see connections, have bright ideas, are innovative, communicative and work well with others and are able to solve problems. In other words, they need creative people.

$\diamond \quad$ Creativity Equips Students' for academic and professional tasks. By promoting creativity, teachers can give all students the opportunity to discover and pursue their particular interests and talents. We are all, or can be, creative to some degrees. Creative students lead richer lives and in the long term, make a valuable contribution to society.

The onus then rests on the language teacher to examine how far this sub-skill has been achieved in the language class through the interactions with technology. It is to be noted that where students have been tasked and drilled effectively on how to make use of modern technology to work independently, originality will not be far fetched and the process is future sustaining. 
Hubbard 2005 says the mark of an effective teaching and learning is in the product (students) who afterward can display mastery by application of the long years of training.

We should not shy-away from the fact that all we want to write won't come to us at the same time hence the need to plan and check our writing all over again and again. The language teacher should try to make the writing class a creative environment.

\section{The Technological Needs of Language Teachers}

For functional education in the $21^{\text {st }}$ century, language teachers must go along with the technological world. In a world that technology has reduced to a global village, no professional can afford to be conservative. Jibowo (2005) says there ought to be an increased interest in the analysis of learners' needs at the level of the language teacher preparation programme.

The above becomes necessary if language teachers and teaching are to be made current and functional. No educational ideology can afford to neglect the teacher factor and stand. Teachers of Language must be equipped with the state-of-the- art technologies so as to be abreast of students. This is possible through interactions within the countries of the world. With the inventions of new technologies, modernity has conquered mediocrity in the advanced countries of the world. There is no country that stands in isolation that can develop. Language teachers are in the position to help in bridging the digital divide since language explains all disciplines and operational words of technological-know-how. Moreover, discoveries and research are essential factors of development. Statistical data are better analyzed with computer and data processing machines. Where these are lacking, this may pave the way for retardation and backwardness and the backwash effect is poverty.

\section{Advance Organizer for the Development of Reading Skills}

Advance organizer can be employed as an effective and essential pre-reading technique for the teaching and learning of reading comprehension. It comes before the reading material thereby preparing the mind for comprehension.

Lawal, Adebola and Adebileje (2005), highlighting the role of Advance Organizer, said it aimed to enhance proactive facilitation and minimize proactive inhibition. This in essence gives vent to the activation of the right schema on any given passage. The organizer helps a lot to bridge the gap between what the learner knows and the new things he/she needs to know based on the given passage. Organizers can be employed to teach the orthographic make-up of any given passage. This makes the terms and pattern clear in application and enhances assimilation. Egbugara (1985) sees advance organizer as an instructional strategy like verbal ability. This is essential for students to benefit immensely from Reading Comprehension Classes. From the other side, it makes the teacher's job easy and smooth-sailing.

Verbal organizer can also go along with pictorial organizer. Pictorial organizer incorporates graphical information with the cognitive structure creating an imaginative effect in the students. All these facilitate teaching and learning of English Language in a second language environment.

\section{Developing Listening Skills through Audio/Radio Technology}

Listening skill is a very important language skill that plays active role in the teaching and learning processes. Ige (2005) quoting Wolvin and Coakley (1985) sees listening as the process of receiving, attending to and assigning meaning to aural stimuli. Listening involves acceptance of input into intake for output. Listening complexity arises as a result of fleetingness of speech. Hence, concerted efforts must be made and appropriate technology must be employed to teach and develop listening skills.

The use of radio/audio technology can be of great assistance to the teachers' effort. This has been employed by the BBC English Radio 'Radio English Direct Programme', which is an English Language teaching series for Africa. This method if well utilized will help a lot in comprehension of ideas, pronunciation of words and application of meanings.

Other areas where new technologies can assist proficiency in English among learners of English as a second language include: the use of CD-Rom to teach word usage and pronunciation; TV and Computer Word Games; E-learning; on-line teaching and learning; and Mobile Learning.

In a world that geo-politics and religion have tried to balkanize, English language as an international language will do a lot to reduce schism and suspicion if it is well taught and understood. The third world can only be developed when correct meanings can be attached to the words and actions of the industrialized world. Hubbard (2005) says, at the bottom of every confusion and alteration of meaning is the misunderstood word or symbol. This in essence becomes false datum which is what is required to establish acrimony and misconception among people. 


\section{Teaching and Learning via Online Simulations}

This is another way of Conceptualizing Learning. This reduces the work of the teacher. Alena (2006) says 'Research shows that computer-asserted learning engages learners, promotes active learning and develops autonomous learning'. The students are taken through a series of stages in a cinematographic presentation. For instance, students may watch a movie that states the components of process writing in the development of writing skills. Later the students may be given another movie showing how the activities in the first movie are brought together. The next stage shows the concatenation of all the earlier advances and this shows how writing is perfected. Now students can attempt to make a similar chain of activities and eventually come up with exciting revelations on writing skills. This shows how learning can be developed and teaching can be enhanced in a Web-based environment.

Technological Advances in the two decades have reduced to the minimum the all-pervading anxiety in the field of teaching and learning. For instance, computers have become crucial components of information processing research management which every effective and diligent scholar requires for an understanding of their fundamental components and processes as well as appreciation and utilization of their capabilities in data analysis.

\section{Word Processors and the Teaching of Writing}

McGreal (1986) says Word Processors can serve as the device par-excellence for promoting the effective learning of the mechanics of good writing. Collier (1982) believes that the word processor promotes surprise, innovations and serendipitous learning. Better ways of expressing ideas emerge with the word processor. Writing in this method favors the employment of the process approach where writers engage in pre-writing, drafting and editing before the final draft. Students writing in a second language face a lot of difficulties as a result of writing in a different language which is foreign to their culture and comprehension. Hence, the process of writing in stages prior to the final writing gives a kind of advantage to the developing writers.

\section{Using Projectors to Establish "Objects" of Study}

More often students encounter problems as a result of lack of the real object of study. There are some objects of study that cannot be brought to the classroom, for instance, immovable objects such as:

\footnotetext{
* Ocean * * Sun *Caterpillar/Tractor * Growing Embryo * Court in Session
}

Hubbard 2003 identified the lack of the object of study as a barrier to understanding. This makes students go blank since he/she has no contact with the object of study. Learning becomes easier when students can see, touch or feel what they are studying about; while the lack of the real object of study leads to frustration and incomprehension. Projectors can be used to give picture of the ocean, a court in session, the sun and other immovable or scarce objects of study.

Projectors can also be used to teach Vocabulary Development in a pictorial form. Terms are explained using pictorial illustrations which research has proved and adjudged a better way of gaining and retaining understanding.

Projectors can also be employed to show speech making mechanisms. Right from the initiation of air in the lungs to the places and manner of articulation of sounds, all these can be made live via electronic projectors; especially where there is no language laboratory.

[Insert Table 1 here]

\section{Benefits}

It is an uncontestable axiom that technology has aided society and many challenges in the field of education are fizzling away as a result of the breakthrough in technology. The benefits of technology in the classroom and in multilingual economy have opened up a whole new learning approach. Knowledge can be easily procured with the help of Internet technology now, and teachers as learning facilitators can assist learning retarded children. Provision of specific object of study (which Hubbard 2007 calls provision of mass) can be made available in classroom. The list is inexhaustible; the following are some of the basic benefits of assistive technology inherent in the interactions of technology with teaching and learning.

$>$ Teachers facilitate learning by suggesting websites to learn from.

$>$ Students and teachers utilize online databases for references.

> Net-surfing provides the application of alternatives and varieties in research and task designing.

$>$ The application of Microsoft Power Point Slides enhances summary writings.

$>$ Creativity is entrenched by in the designing of new ideas from concatenated facts from the internet.

$>$ Currency of facts is made possible as a result of academic web interactions. 
$>$ Students can learn in the absence of the teacher.

$>$ Peer editing and consultation through the net become a recursive decimal in writing skill development.

$>\quad$ Practising and mastering of new vocabulary using Microsoft Encarta, soft-ware lexicon and www.quizlet.com in world language classes.

$>$ Relation of ideas and interaction using social media such as twitters, Face-book, You-tube and Podcasts.

$>$ Cross culture education is strengthened.

$>$ Participation in online discussions using teleconferencing is possible.

$>$ Feedback is faster and a wide coverage of consultations are made possible through technology.

$>$ Independent or self-paced learning has come to the fore.

\section{Barriers}

Digital divides: Availability and access to new technologies in Africa is still disproportionately low when compared with what exists in the developed world. The little progress made in Africa on access to mobile phones and Internet is suspect. The so-called 'new' technologies that are available in Africa are not the 'latest' technologies. This again, raises the issue of 'Multiple Divides'.

Table 2 from the World Bank survey of available technologies compares the 'haves' and the 'have nots'.

[Insert Table 2 here]

Perhaps in the next decade at the latest, the world may go digital. Most of the advanced countries parastatal operations are already digitalized. For instance, the transition from analogue to digital broadcasting is already under way or completed in some European countries and the US. The rest of the world is in line - and too many people have no idea what this is all about. It as at the behest of this scenario that Atkins 2005 says Poorer countries, particularly from Africa, are expected to repeat calls in Geneva for a "Digital Solidarity Fund" to help finance the infrastructure they say is needed to close the perceived technology gap. Nevertheless, some government of the developing nations are making frantic effort by indicating intentions to go digital.

1. To bridge the digital divide between the developed and less developed countries of the world, the world's most spoken language - apparently the language of the industrialized world must be understood.

2. English Language teachers in multilingual nations can be better equipped with the use of new technologies to make teaching easier, faster and better taught.

3. Research on how to use the state-of-the-art technologies to explain complex areas of language teaching and learning will eradicate frustrations of learning English as a second language in multilingual settings.

4. Therefore, language teachers should be given orientation on how to use new technologies.

5. The provision of these modern gadgets like computers, advanced organizers and radio/audio equipment must be made available.

6. Language laboratories must be made available for all in the field of language education.

\section{Doldrums Economy}

A worthwhile economy is knowledge driven. The African economy cannot, and should not, be further destroyed with primitive economic initiatives where the economy of the developed countries is technology driven and growing. Digital enhanced learning should be designed to be futuristic and ambitious to reverse the poverty trends in African Nations. Technology needs a lot of capital for projection and progress. The realities of globalization, through the rise of information and communication technologies and in particular the knowledge society, have been powerful forces of change for the market economy; this in turn can have noticeable effect on education.

\section{Divergent Opinions}

The entire world is balkanized along religious, political and economic interests which is making the process of turning divide to dividends a mission impossible. Technology is applied to further negative selfish interest. Phones lines are hacked and there is a wide-wild negative transfer and application of technology in certain respect. It is quite dishearten that many do not know the benefits inherent in academic web interactions. So many are least aware of the advantages, knowledge and skill acquisition, innovating the curriculum and getting better approaches for teaching and learning as a result of technology collaborations across different borders.

\section{Implications for Stakeholders}

1. Institutionalized digitalized education. E-learning learning should be supported by Government and made 
accessible to prospective learners from elementary to higher education.

2. Internationalization of e learning. African countries should take advantage of the wireless devices and mobile technology to evolve flexible 'cross-country' curricula that will connect each country with the rest of the world.

3. Integration of technology-driven learning initiates like cross-cultural learning, Distance learning, Open learning and mobile learning for optimum learning output.

4. Inter/Intra country collaborations in Africa for capacity building for the enrichment of pedagogy in Africa.

5. Export latest technologies that will enhance e- learning into Africa for easy access to real new teaching and learning technologies.

6. Examine the current level of digital education in Africa in relation to e-education in the developed world in order to offer necessary assistance and hence narrow the widening divides.

7. Exclude poor nations from high export tariffs and stringent conditions attached to transfer of technologies that make new technologies unaffordable by such nations.

8. Expand available opportunities and programmes for capacity training for Africans and third world countries in the use of new technologies.

9. Exhibit clear intentions to bridge the widening gaps between Africa and the developed world regarding access to latest technologies.

10. Explore a systematic procedure for internationalization and globalization of education through global emphasis on blended learning.

11. Express, through global connections, the need to tackle social exclusion of the less privileged nations and promote equality among people without prejudice to color, race, religion, culture and social status.

12. Importation of new and latest technologies without minding the cost, for realistic globally acceptable educational programmes.

\section{Conclusion}

The indicators and veracities of the effects of technology have made and continue to make a pronounceable demarcation between developments in the past and present. The realities of information and communication technologies, the market economy innovation, faster and lesser risk-taking approaches for dialogues and consultations, inter and intra-national professional movements are opening new vistas of knowledge awareness for different professionals. On top of these is the upshot of technology in the teaching and learning arena. Language educators are having thrilling privileges through the application and utilization of the state of the art technology. Teachers and students have revealing experience to account for as each group is making rewardable discoveries through the academic interface of technology and educational research. Scholars don't need to be looking for encyclopedia Americana or Britannica before technical usages of words are known. The Microsoft Encarta soft-ware has better to offer. Purposeful interactions among the different scholars from the different walks of life are nurturing a global capacity building that may pave way for harnessing the products of academic consultations through net-surfing and other cyber-activities. All these are clear signal that much will be realized through digital education. Interaction goes on within and outside the geographical boundaries of every nation. One must speak and the utterance must be internationally acceptable, socially intelligible and educationally impressive. Development can not be achieved in isolation. The role of technology in language skills development cannot be down-played in every society. The digitally conscious world has a lot to offer; then all avenues must be sought and opportunities utilized for the emancipation of the less developed.

\section{References}

Akinwamide, T. K. (2007). Process Approach and Creativity in Essay Writing. Unpublished Ph. D Dissertation, AAUA, Nigeria.

Alena, YLY. (2006). Teach Less Learn More; Using Online Simulations For Conceptual Learning. C.T.L. National University of Singapore. Kent Ridge. Crescent, Singapore 119260.

Anne-Katrin, A. (2009). on People, Spaces, Deliberation. http://blogs.worldbank.org/publicshere

Carlson, S. (2005). The Net-Generation in the Classroom. The Chronicle of Higher Education, 52(7), A34-A37.

Collier, R. M. (1982). The Influence of Computer Based Text Editors on the Revision Strategies of In-experienced

Writers. ERIC Document Reproduction Service No. ED 2H 998. 
Egbugara V. O. (1985). The Effect of Verbal Ability on the Use of an Organizer in Physics. (Unoh, S. O. ed). Literary and Reading in Nigeria, 3, Zaria, ABU Press.

Hubbard, R. (2003). Advanced Learning Tools for Educators. APS USA.

Ige. B. (2005). Teaching Listening Skills in Language. Federal College of Education, Ogun State, Nigeria.

Jibowo A. V. (2005). Training Needs of English Language Teachers for Functional Education. OOU, Nigeria.

Lawal, A. Adebola, \& Adebileje, O. A. (2005). Language Communication and Education. Counstellation Books Ibadan.

McGreal, R. (1986). Word Processors and the Teaching of Writing. English Teaching Forum U.S.A.

Murphy et al. (2002). Enhancing Learning opportunities in Africa. Human Development Sector, Africa Region. The World Bank.

Table 1. Practising the Technological Oriented Pedagogy

\begin{tabular}{|l|l|l|l|l|}
\hline $\begin{array}{l}\text { Language } \\
\text { skills }\end{array}$ & Tech-involved & $\begin{array}{l}\text { Inherent } \\
\text { Learning } \\
\text { Styles }\end{array}$ & Roles of teacher & Cyber-tasks \\
\hline Listening & $\begin{array}{l}\text { You-tube and Dictaphones for } \\
\text { presentations of Dicto-comp }\end{array}$ & Audio-visual & $\begin{array}{l}\text { Facilitating the } \\
\text { processes } \\
\text { identifications of } \\
\text { focal points }\end{array}$ & $\begin{array}{l}\text { of } \\
\text { of } \\
\text { similar examples }\end{array}$ \\
\hline Speaking & $\begin{array}{l}\text { Projector, power DVD to } \\
\text { record and play students } \\
\text { pronunciation of some words }\end{array}$ & Verbal & Moderating inputs & $\begin{array}{l}\text { Speak on three different } \\
\text { points and use } \\
\text { Hyperlink for } \\
\text { connectivity of ideas }\end{array}$ \\
\hline Reading & $\begin{array}{l}\text { Reading from the Net articles } \\
\text { on Brainstorming Socio- Verbal }\end{array}$ & $\begin{array}{l}\text { Teacher encourages } \\
\text { students to navigate } \\
\text { using } \\
\text { Council Stitish } \\
\text { links for relevant } \\
\text { ideas } \\
\text { additional information } \\
\text { on Brainstorming }\end{array}$ \\
\hline Writing & $\begin{array}{l}\text { Write on 'Dividends of } \\
\text { modern technology in the } \\
\text { classroom' }\end{array}$ & $\begin{array}{l}\text { Socio-Solitary class is divided } \\
\text { intogroups }\end{array}$ & $\begin{array}{l}\text { Browse for facts on the } \\
\text { Net }\end{array}$ \\
\hline
\end{tabular}

(Akinwamide and Adedara 2012)

Table 2. Education technologies available per 1000 persons

\begin{tabular}{|l|l|l|l|}
\hline Region/country & Radios (1996) & Television (1997) & Personal computers (1997) \\
\hline Africa & 54 (Angola) & 5 (Ethiopia) & $>1$ (Burkina Faso) \\
& 238 (Ghana) & 26 (Uganda) & (Zimbabwe) \\
& 256 (Malawi) & 64 (Ivory Coast) & \\
& 316 (South Africa) & & 4 (Pakistan) \\
& 195 (China) & 124 (Cambodia) & 399 (Singapore) \\
& 432 (Malaysia) & 69 (India) & 3 (Guatemala) \\
& 283 (Nicaragua) & 294 (Ecuador) & 54 (Chile) \\
\hline LAC & 610 (Uruguay) & 323 (Jamaica) & 348 (Switzerland) \\
& 404 (Lithuania) & 469 (Czech Republic) & 407 SA) \\
\hline ECA & 1,078 (Canada) & 847 (USA) & \\
\hline
\end{tabular}

Source: World Bank in Murphy et al (2002) 